\title{
Investigation of the Polyphenol Composition, Biological Activities, and Detoxification Properties of Some Medicinal Mushrooms from Turkey
}

\author{
Türkiye'deki Bazı Tıbbi Mantarların Polifenol Bileşiminin, Biyolojik \\ Aktivitelerinin ve Detoksifikasyon Özelliklerinin Araştırılması
}

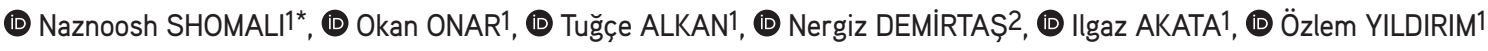 \\ ${ }^{1}$ Ankara University, Faculty of Science, Department of Biology, Ankara, Turkey \\ 2The Ministry of Food, Agriculture and Livestock, Food Control Laboratory, Food Chemical Analysis Laboratory, Ankara, Turkey
}

\begin{abstract}
Objectives: Ethanolic extracts of the mushroom species Ganoderma adspersum, Inonotus hispidus, Russula chloroides, and Sarcodon imbricatus were investigated for their polyphenolic contents and biological activities.

Materials and Methods: The radical scavenging activity of the extracts was evaluated by 2,2-diphenyl-1-(2,4,6-trinitrophenyl) (DPPH) method and their polyphenolic compounds were determined by high performance liquid chromatography (HPLC) analysis. Furthermore, the activity effects of mushroom extracts on the enzyme glutathione-S-transferase (GST) were also examined. Additionally, the antimicrobial activity of mushroom extracts was evaluated by disc diffusion method.

Results: Ethanolic extract of I. hispidus demonstrated the highest total phenolic content and total flavonoid contents, with $227.23 \pm 4.96$ mg gallic acid equivalent/g and $42.14 \pm 0.20$ quercetin equivalent/g, respectively. The highest DPPH radical scavenging activity was observed for ethanolic extracts of $I$. hispidus, with $10.687 \pm 1.643 \mu \mathrm{g} / \mathrm{mL} \mathrm{IC}{ }_{50}$. HPLC analysis demonstrated that $R$. chloroides was composed of ferulic acid, gallic acid, and myricetin compounds. The highest GST enzyme activity effect was detected with the ethanol extracts of I. hispidus and S. imbricatus. None of the mushroom extracts demonstrated significant inhibition of the bacterial strains used.

Conclusion: These results indicate that I. hispidus may be proposed as a new potential source of natural medicine and its potential may be related to its polyphenolic content, which needs further investigation.
\end{abstract}

Key words: Wild mushrooms, polyphenolic compounds, antioxidant, glutathione-S-transferase, detoxification properties

Öz

Amaç: Ganoderma adspersum, Inonotus hispidus, Russula chloroides ve Sarcodon imbricatus mantar türlerinin etanollü ekstreleri, polifenolik içerikleri ve biyolojik aktiviteleri açısından araştırılmıştır.

Gereç ve Yöntemler: Ekstrelerin radikal süpürücü etkileri 2,2-difenil-1-(2,4,6-trinitrofenil) (DPPH) yöntemi kullanılarak ve polifenolik içerikleri yüksek performanslı sıvı kromatografisi (HPLC) analizleri ile belirlendi. Ayrıca, mantar ekstrelerinin glutatyon-S-transferaz (GST) enzim aktivatör etkisi incelendi. Bunlara ek olarak, mantar ekstrelerinin antimikrobiyal aktivitesi, disk difüzyon yöntemi ile değerlendirildi.

Bulgular: I. hispidus'un etanol ekstresi sırasıyla $227.23 \pm 4.96 \mathrm{mg} \mathrm{GAE} / \mathrm{g}$ ve $42.14 \pm 0.20 \mathrm{QE} / \mathrm{g}$ değerleri ile en yüksek toplam fenol ve toplam

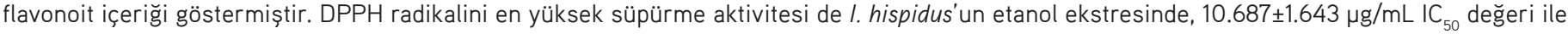
gözlenmiştir. HPLC analizi, R. chloroides'in ferulik asit, gallik asit ve mirisetin bileşiklerini içerdiğini göstermiştir. En yüksek GST enzim aktivatör etki I. hispidus ve S. imbricatus'un etanol ekstrelerinde belirlenmiştir. Mantar ekstrelerinin hiçbiri kullanılan bakteri suşları üzerinde belirgin bir inhibisyon göstermemiştir.

Sonuç: Bu sonuçlar, ileri araştırmalar gerektirip I. hispidus'un yeni bir potansiyel doğal ilaç kaynağı olabileceğini ve bu etkinin polifenolik içerik ile ilişkili olabileceğini göstermektedir.

Anahtar kelimeler: Yabani mantarlar, polifenolik bileşikler, antioksidan, glutatyon-S-transferaz, detoksifikasyon özellikleri

*Correspondence: E-mail: naznoosh_shomali@yahoo.com, Phone: +90 5542816336 ORCID-ID: orcid.org/0000-0002-7366-1569

Received: 08.10.2017, Accepted: 25.01.2018

-Turk J Pharm Sci, Published by Galenos Publishing House. 


\section{INTRODUCTION}

Recently, exploration of natural sources for novel bioactive compounds has gained considerable attention and it has helped to provide therapeutic drugs and principal compounds. Mushrooms, traditionally known as a valuable source of natural bioactive compounds, have been studied widely for their therapeutic capabilities. Medicinal mushrooms have been proved to contain many biologically active compounds, and many effective drugs and agrochemical fungicides are derived due to secondary metabolites extracted and isolated from mushrooms. ${ }^{1,2}$ Some of the most recent isolated and identified compounds from mushrooms have shown promising antiviral, antibacterial, antioxidant, antidiabetic, immunomodulatory, antitumor, and hepatoprotective properties. Moreover, they contain a number of valuable nutrients, including protein, enzymes, B vitamins (especially niacin), and vitamin D.,4

Ganoderma adspersum is a species of Basidiomycetes. Several species of Ganoderma are rich in bioactive compounds such as triterpenoids and polysaccharides. Traditionally, Ganoderma species have been widely used in the treatment of hepatopathy, chronic hepatitis, nephritis, hypertension, arthritis, neurasthenia, insomnia, bronchitis, asthma, and gastric ulcers. ${ }^{5}$ They were also investigated for a variety of potential therapeutic benefits such as reducing blood pressure, as well as their blood cholesterol, antioxidant, anticancer, antidiabetic, antiviral, and antibacterial properties. ${ }^{6-9}$ Wong et al. ${ }^{10}$ demonstrated that extract of Ganoderma lucidum prepared in hot water had a protective effect on the cardiovascular system. Their study suggested that it reduces superoxide-induced damage to the heart. Additionally, Çayan-Tel et al."1 isolated applanoxidic acid $G$, applanoxidic acid $E$, applanoxidic acid $A$, and 22-stigmastenol compounds from $G$. adspersum and investigated the antioxidant and anticholinesterase activities of mushroom extracts and isolated pure compounds. They reported that applanoxidic acid $E$ and 22-stigmastenol showed significant antioxidant activities in the inhibition of lipid peroxidation. The same authors also demonstrated that applanoxidic acid $G$ and 22-stigmastenol compounds exhibited moderate inhibiting activity against the enzyme butyrylcholinesterase.

Sarcodon imbricatus (Bankeraceae) is an edible mushroom. It is commonly known as the shingled hedgehog or scaly hedgehog. In folk medicine, it is used for lowering cholesterol levels, relaxing muscles, and regulating blood circulation.12 Many studies have demonstrated that $S$. imbricatus is a good source of sterol compounds. In previous studies, the compounds ergosterol, ergostane, and cholestane have been isolated from S. imbricatus. ${ }^{13,14}$ In particular, the presence of ergosterol peroxide in the methanol extract of $S$. imbricatus is important because it shows various biological activities, such as antileukemic, anticancer, apoptotic-inducing, and anti-inflammatory.15-17

Inonotus hispidus (Hymenochaetaceae) is commonly known as shaggy bracket. It is known as a pathogen on plants. However, it has numerous medicinal properties. In previous studies, the antiviral activity of two phenolic compounds, hispolon and hispidin, which were isolated from the fruit bodies of I. hispidus, was investigated. The results obtained showed that hispidin and hispolon exhibit considerable antiviral activity against influenza viruses type $A$ and $B{ }^{18}$

Russula chloroides is a member of the genus Russula, which belongs to the family Russulaceae. Even though there is a high number of species, the biological properties of Russula have not been investigated in detail.

Glutathione-S-transferases (GSTs) comprise a phase ॥ metabolic isozyme family existing in both eukaryotes and prokaryotes. These isozymes are best known for their ability to catalyze the conjugation of the reduced form of glutathione (GSH) to xenobiotic substrates for the purpose of detoxification. This eukaryotic species has multiple GST isozymes that are found in the cytosol and membrane. They catalyze the process of glutathione conjugation in electrophilic regions using a sulfhydryl group, which increases the solubility of xenobiotic and endogenous compounds. During this process, endogenous compounds like peroxidase lipids are detoxified together with the disintegration of compounds and xenobiotics. ${ }^{19,20}$

The main aims of this work were to investigate the polyphenolic contents and biological activities of ethanol extracts of several wild mushrooms from the local environment (G. adspersum, I. hispidus, $R$. chloroides, and S. imbricatus). Furthermore, the GST enzyme activity of these mushroom extracts was evaluated for the first time.

\section{MATERIALS AND METHODS}

\section{Chemical materials}

All chemicals used in the study were supplied by Sigma Aldrich (USA), except 1-chloro-2,4-dinitrobenzene (CDNB), which was purchased from Gerbu (Germany), and nutrient broth, malt extract, and malt extract agar, which were obtained from Merck (USA).

\section{Mushroom materials}

Mushroom samples of G. adspersum, I. hispidus, R. chloroides, and S. imbricatus were collected from Belgrad Forest, İstanbul, and Yomra, Trabzon. They were identified by Dr. Ilgaz Akata and they are kept at the Fungarium of Ankara University with the code numbers Akata 6355, Akata 6052, Akata 5895 and Akata \& Yuzun 757.

\section{Extraction of mushrooms}

For ethanol extraction, $10 \mathrm{~g}$ of dried samples were weighed and ground into a fine powder with liquid nitrogen, and then mixed with $100 \mathrm{~mL}$ of ethyl alcohol (96\%) at room temperature for $24 \mathrm{~h}$. The extract obtained was filtered using Whatman No. 1 paper. In the next step, the existing ethanol was removed using a rotary evaporator at $40^{\circ} \mathrm{C}$ and the remaining solution was lyophilized. Finally, the samples were then kept in dark and cold $\left(4^{\circ} \mathrm{C}\right)$ conditions to prevent oxidative damage..$^{21}$

\section{Determination of total phenolic content}

The Folin-Ciocalteu method was used to evaluate the content of total phenolic compounds of mushroom extracts. ${ }^{22}$ Each $0.1 \mathrm{~mL}$ of extract solution was mixed with $2 \mathrm{~mL}$ of a $2 \%(\mathrm{w} / \mathrm{v})$ 
sodium carbonate solution using strong vortexing. After $5 \mathrm{~min}$, $0.1 \mathrm{~mL}$ of $50 \%$ Folin-Ciocalteu reagent (w/v) was added and the resulting mixture was vortexed and then incubated for $1 \mathrm{~h}$ at room temperature. Afterwards, the absorbance of each mixture was measured at $750 \mathrm{~nm}$ with a UV-VIS spectrophotometer. The results were evaluated using $0.05,0.1,0.15$, and $0.2 \mathrm{mg} / \mathrm{mL}$ gallic acid (GA) as standard curve and recorded as milligrams of GA equivalent per gram of dried sample.

\section{Determination of total flavonoid content}

The aluminum chloride colorimetric method was utilized to determine the total content of flavonoids in samples. ${ }^{23}$ This test was conducted by mixing $0.1 \mathrm{~mL}$ of each extract solution with $0.15 \mathrm{~mL}$ of $95 \%$ ethanol, $0.01 \mathrm{~mL}$ of $10 \%$ aluminum chloride, 0.01 $\mathrm{mL}$ of $1 \mathrm{M}$ sodium acetate, and $0.25 \mathrm{~mL}$ of dimethyl sulfoxide. The mixture was then incubated at room temperature for 30 min and the absorbance of the reaction was measured at 415 $\mathrm{nm}$ with a UV-VIS spectrophotometer. Finally, the standard curve was produced using different concentrations of quercetin solutions $(0.025,0.05,0.1,0.15$, and $0.2 \mathrm{mg} / \mathrm{mL}$ ). The total flavonoid content of the extract was expressed as milligrams of quercetin equivalent per gram of dried sample.

\section{High performance liquid chromatography analysis}

The high performance liquid chromatography (HPLC) assay was performed to investigate the phenolic compound profiles of ethanol mushroom extract. For this purpose, a lyophilized sample was dissolved in $2 \mathrm{~mL}$ of $80 \%$ methanol and then filtered using $0.45 \mu \mathrm{m}$ cellulose membrane filters before injection. Aliquots of $20 \mu \mathrm{L}$ were injected into the ultraperformance liquid chromatography system (Shimadzu Nexera X2, Shimadzu Corporation, Kyoto, Japan) equipped with a diode array detector set at 280,320, and $360 \mathrm{~nm}$. A 250×4.6 mm i.d., $5 \mu \mathrm{m}$, C18 ODS-3 column (Intersil) was used. The mobile phase was composed of $5 \%$ formic acid (A) and methanol (B) at flow rate of $0.9 \mathrm{~mL} / \mathrm{min}$. The elution gradient was $5-80 \%$ (B) from 0 to $60 \mathrm{~min}$. Calibration curves for each phenolic standard (the best wavelength) were prepared for quantification. For this purpose, myricetin, quercetin hydrate, ferulic, gallic, vanillic, caffeic, chlorogenic, and p-coumaric acids were used as positive controls. The HPLC analysis was carried out by the Central Laboratory of the General Directorate of the Food and Control Institute.

\section{Free radical scavenging activity by DPPH assay}

The radical scavenging activities of mushroom extracts were measured according to the methods described by Sharma and Bhat ${ }^{24}$ with some modifications. The antioxidant activities of the extracts were determined on the basis of the radical scavenging effect of the DPPH-free radical. According to the procedure, 0.2 $\mathrm{mL}$ of mushroom extract at different concentrations was mixed with $0.5 \mathrm{~mL}$ of DPPH ethanol solution $(0.12 \mathrm{mM})$ and $0.5 \mathrm{~mL}$ of ethanol (96\%). Then samples were incubated for $30 \mathrm{~min}$ at room temperature and in darkness. Next absorbance was read at $517 \mathrm{~nm}$ by UV-VIS spectrophotometer with GA employed as reference. The DPPH radical scavenging activity of each sample was expressed as the half maximal inhibitory concentration
$\left(\mathrm{IC}_{50}\right)$ value and calculated from the dose-response inhibition curve.

\section{Isolation of cytosol from bovine liver}

The bovine liver used in this study was provided by a slaughterhouse in Kazan, Ankara, Turkey. The liver samples were homogenized in $10 \mathrm{mM}$ potassium phosphate buffer $(\mathrm{pH}$ 7.0), containing $0.15 \mathrm{M} \mathrm{KCl}, 1 \mathrm{mM}$ EDTA, and $1 \mathrm{mM}$ DTT, using a glass Teflon homogenizer and then centrifuged at $10,000 \times \mathrm{g}$ for $20 \mathrm{~min}$. The supernatant was filtered through cheesecloth and the filtrate was centrifuged at $30,000 \times$ g for $60 \mathrm{~min}$. The collected supernatants were filtered again and the resultant filtrate was referred to as cytosol. ${ }^{25}$ The prepared homogenates were kept at $-80^{\circ} \mathrm{C}$ for future analysis. Total protein content was determined by the Lowry method. ${ }^{26}$

\section{Testing activity of GST}

GST activity was determined against the substrate CDNB by monitoring thioether formation at $340 \mathrm{~nm} \cdot{ }^{27}$ In line with the protocol, an assay mixture composed of mushroom extract solutions (concentration in the range of $10-0.625 \mathrm{mg} / \mathrm{mL}$ ), 200 $\mathrm{mM}$ potassium phosphate buffer ( $\mathrm{pH}$ 6.5) with $20 \mathrm{mM} \mathrm{CDNB}$ and $50 \mathrm{mM} \mathrm{GSH}$, and bovine liver cytosolic fractions was prepared and used as the enzyme source to measure GST activity. GSHCDNB conjugate formation was followed in $1 \mathrm{~mL}$ total volume assay by UV-VIS spectrophotometer at $340 \mathrm{~nm}$ for $2 \mathrm{~min}$. Initial rates of enzymatic reactions were determined as nanomoles of the conjugation product of GSH and reported as $\mathrm{nmol} / \mathrm{min} / \mathrm{mL}$.

\section{Antimicrobial assay}

The antibacterial activities of mushroom extracts were determined against the gram (+) bacterial strain Staphylococcus aureus ATCC 25923 and the gram (-) bacterial strains Escherichia coli ATCC 25922 and Pseudomonas aeruginosa ATCC 27853 using the disc diffusion method. ${ }^{28}$ The bacterial strains were incubated at $37^{\circ} \mathrm{C}$ in Nutrient Broth culture for $24 \mathrm{~h}$. Inoculants were prepared by transferring colonies of each organism into $0.9 \%$ sterile saline solution until the visible turbidity was equal to $0.5 \mathrm{McF}$ arland standard containing approximately $10^{8} \mathrm{cfu} / \mathrm{mL}$ bacteria. Nutrient Agar was used as culture for antibacterial activities. Afterwards, $0.02 \mathrm{~mL}$ of each extract was applied to 6-mm-diameter sterile paper discs and to eliminate any residual solvent the discs were left to dry overnight at room temperature. The surface of the plates was inoculated by using prepared inoculant containing saline suspension of microorganisms. The discs were placed in the center of the agar surface of each petri plate. Zones of inhibition were measured in $\mathrm{mm}$ after incubating the petri plates at $30^{\circ} \mathrm{C}$ for $24 \mathrm{~h}$. For this study, streptomycin (10 $\mathrm{mg}$ ) and tetracycline (30 mg) were used as positive controls for all samples.

\section{RESULTS}

The ethanol extracts of $G$. adspersum, I. hispidus, $R$. chloroides, and $S$. imbricatus were used to investigate their polyphenolic contents and antioxidant and antimicrobial activities. Moreover, for the first time, their effects on GST activity were evaluated. With this research, each extract was prepared by dissolving 
$10 \mathrm{~g}$ of dry samples in $100 \mathrm{~mL}$ of ethanol (96\%) solvent. The extraction yields of $G$. adspersum, I. hispidus, $R$. chloroides, and S. imbricatus were in the range of $3.71 \%$ to $13 \%$. In addition, total phenolic contents, total flavonoid contents, and radical scavenging activity of the extract were determined using spectrophotometric assays. The percentage of the yields, total phenolic contents, total flavonoid contents, and results of DPPH scavenging activity are shown in Table 1. The total phenolic contents of extracts were $227.23 \pm 4.96$ to $3.125 \pm 0.12 \mathrm{mg} \mathrm{GAE} / \mathrm{g}$ of the dry samples. The total flavonoid contents varied from $42.14 \pm 0.20$ to $1.99 \pm 0.27 \mathrm{mg} Q E / g$ of the dry samples. Phenolic and flavonoid contents of the ethanol extract of $I$. hispidus were $227.23 \pm 4.96 \mathrm{mg} \mathrm{GAE} / \mathrm{g}$ and $42.14 \pm 0.20 \mathrm{QE} / \mathrm{g}$, respectively, and these are higher values compared to the other mushroom species. Free radical scavenging activity results are presented as percentage of DPPH radical scavenging activity of different extracts $(\mathrm{mg} / \mathrm{mL})$ according to concentration inhibition curves and $I C_{50}$ values. The results showed that the highest amount of free radical scavenging activity was in the extracts of $G$. adspersum and $I$. hispidus, with $48.002 \pm 0.861$ and $10.687 \pm 1.643$ $\mu \mathrm{g} / \mathrm{mL} \mathrm{IC} \mathrm{C}_{50}$, respectively (Figure 1 , Table 1 ). The $\mathrm{IC}_{50}$ value for GA solution, which was used as a reference, was $4.000 \pm 0.002$ $\mu \mathrm{g} / \mathrm{mL}$.

Table 1. The percent (\%) yield, total phenolics content, total flavonoid content, and DPPH results of mushroom extracts

\begin{tabular}{lllll} 
Mushroom & $\begin{array}{l}\text { Yield } \\
(\%)\end{array}$ & $\begin{array}{l}\mathrm{TPC}(\mathrm{mg} \\
\mathrm{GAE} / \mathrm{g})\end{array}$ & $\begin{array}{l}\mathrm{TF}(\mathrm{mg} \\
\mathrm{QE} / \mathrm{g})\end{array}$ & $\mathrm{DPPH} \mathrm{IC}_{50} \mu \mathrm{g} / \mathrm{mL}$ \\
\hline $\begin{array}{l}\text { Inonotus } \\
\text { hispidus }\end{array}$ & 3.71 & $227.23 \pm 4.96$ & $42.14 \pm 0.20$ & $10.687 \pm 1.643$ \\
\hline $\begin{array}{l}\text { Ganoderma } \\
\text { adspersum }\end{array}$ & 6.44 & $109.20 \pm 8.83$ & $13.6 \pm 0.22$ & $48.002 \pm 0.861$ \\
\hline $\begin{array}{l}\text { Sarcodon } \\
\text { imbricatus }\end{array}$ & 11.88 & $13.20 \pm 0.1$ & $5.45 \pm 0.11$ & $950.878 \pm 11.418$ \\
\hline $\begin{array}{l}\text { Russula } \\
\text { chloroides }\end{array}$ & 13.00 & $3.125 \pm 0.12$ & $1.99 \pm 0.27$ & $2637.709 \pm 55.857$ \\
\hline \begin{tabular}{l} 
Gallic acid \\
\hline
\end{tabular} & - & - & - & $4.000 \pm 0.002$ \\
\hline
\end{tabular}

DPPH: 2,2-diphenyl-1-(2,4,6-trinitrophenyl), TPC: Total phenolic contain, TF: Total flavonoid
The phenolic profiles of the ethanol extracts from G. adspersum, I. hispidus, R. chloroides, and S. imbricatus were studied by HPLC assay. In this assay, myricetin, quercetin hydrate, ferulic, gallic, vanillic, caffeic, chlorogenic, and $p$-coumaric acids were used as references. According to these results, $R$. chloroides included ferulic acid, GA, and myricetin compounds, with 4.6020 \pm 0.23 , $0.3027 \pm 0.02$, and $1.7460 \pm 0.09 \mathrm{mg} / \mathrm{g}$ values, respectively. Moreover, myricetin was found in all of the ethanol extract solutions. However, none of the extract solutions contained vanillic, caffeic, chlorogenic, or $p$-coumaric acids. The results are given in Table 2 .

With this study, it was shown that the G. adspersum, I. hispidus, $R$. chloroides, and S. imbricatus extracts had effects on GST enzyme activity. The extracts were used within the range of $0.625-10 \mathrm{mg} / \mathrm{mL}$ concentration while measuring the activity on GST. The best activity profile for GST was observed with the crude ethanol extracts of I. hispidus and S. imbricatus (Figure 2 ). The activities of the ethanol extracts of mushrooms are presented in Figure 2.

Moreover, we also demonstrated the antimicrobial activity of $G$. adspersum, I. hispidus, $R$. chloroides, and S. imbricatus extracts against the $S$. aureus, $E$. coli, and $P$. aeruginosa strains by disc diffusion assay. However, in comparison with the positive

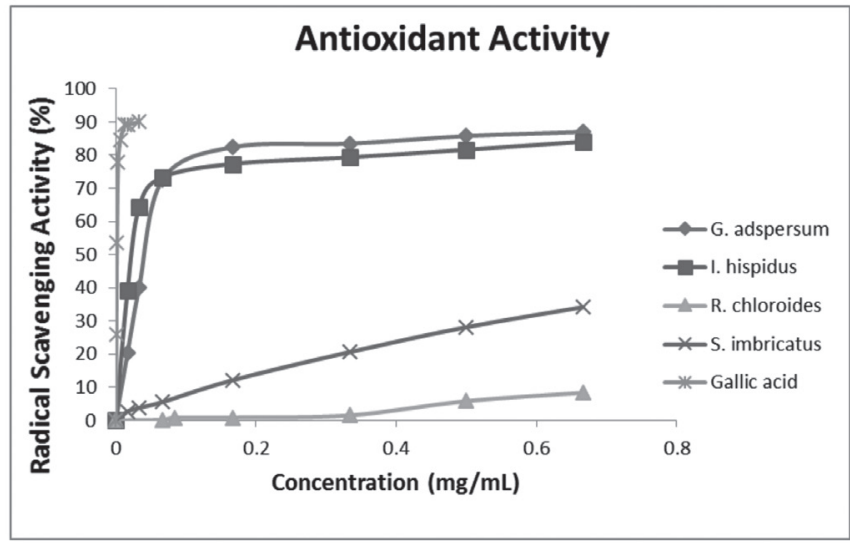

Figure 1. Percent free radical scavenging activity of mushroom extracts. The data represent the mean \pm standard deviation $(n=3)$

Table 2. HPLC analysis of the phenolic profiles of mushrooms extracts

\begin{tabular}{|c|c|c|c|c|}
\hline \multirow{2}{*}{ Mushroom } & Inonotus hispidus & Ganoderma adspersum & Sarcodon imbricatus & Russula chloroides \\
\hline & \multicolumn{4}{|c|}{ Content of selected polyphenol compound $\mathrm{mg} / \mathrm{g}$} \\
\hline Caffeic acid & - & - & - & - \\
\hline Chlorogenic acid & - & - & - & - \\
\hline$p$-coumaric acid & - & - & - & - \\
\hline Ferulic acid & - & - & - & $4.6020 \pm 0.23$ \\
\hline Gallic acid & - & - & $0.7510 \pm 0.04$ & $0.3027 \pm 0.02$ \\
\hline Myricetin & $0.6010 \pm 0.03$ & $0.6370 \pm 0.03$ & $2.8910 \pm 0.15$ & $1.7460 \pm 0.09$ \\
\hline Quercetin hydrate & - & $1.3040 \pm 0.07$ & - & - \\
\hline Vanillic acid & - & - & - & - \\
\hline
\end{tabular}




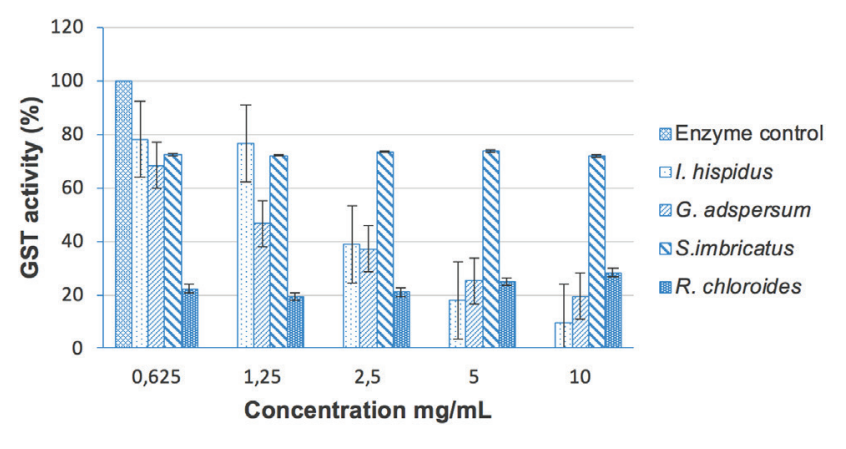

Figure 2. Effects of mushroom extracts on glutathione-S-transferase enzyme activity (\%). The data represent the mean \pm standard deviation $(n=3)$

controls, none of the mushroom extracts showed significant inhibitory effects on the bacterial strains. The results of the disc diffusion assay of mushroom extracts are presented in Table 3.

\section{Table 3. Results of disc diffusion of mushroom extracts}

\begin{tabular}{llll} 
Mushroom & $\begin{array}{l}\text { Escherichia coli } \\
\text { ATCC 25922 }\end{array}$ & $\begin{array}{l}\text { Staphylococcus } \\
\text { aureus } \\
\text { ATCC 25923 }\end{array}$ & $\begin{array}{l}\text { Pseudomonas } \\
\text { aeruginosa } \\
\text { ATCC 27853 }\end{array}$ \\
\cline { 2 - 4 } & Inhibition zone (mm) & 10 \\
\hline $\begin{array}{l}\text { Inonotus hispidus } \\
\begin{array}{l}\text { Ganoderma } \\
\text { adspersum }\end{array}\end{array}$ & 10 & 10 & 8 \\
\hline $\begin{array}{l}\text { Sarcodon } \\
\text { imbricatus }\end{array}$ & 9 & 10 & 9 \\
\hline $\begin{array}{l}\text { Russula chloroides } \\
\text { Streptomycin }\end{array}$ & 8 & 9 & 8 \\
\hline Tetracycline & 13 & 8 & 15 \\
\hline
\end{tabular}

\section{DISCUSSION}

In the present study, we found that the ethanol extract of $G$. adspersum contained significant amounts of phenolic and flavonoid compounds. It was also shown that $G$. adspersum extract exhibited significant free radical scavenging effect. Moreover, the ethanol extract from $G$. adspersum included remarkable amounts of myricetin and quercetin hydrate compounds, which have benefits to health. These compounds possess antioxidant and anticancer properties. ${ }^{29-31}$ It should also be noted that $G$. adspersum extract revealed weak antimicrobial activity against $S$. aureus, $E$. coli, and $P$. aeruginosa strains. Kuruni et al. ${ }^{32}$ evaluated the antioxidant activity of methanol extracts of G. applanatum using in vitro models. They reported that high amounts of phenolic and flavonoid compounds in the extract were determined and, therefore, the extract exhibited a significant antioxidant capacity in the DPPH radical scavenging assay.

Furthermore, we demonstrated that the ethanol extract from S. imbricatus included small amounts of phenolic and flavonoid compounds; therefore, it showed lower antioxidant and antimicrobial activity profiles. Using the HPLC assay we found that the ethanol extract of $S$. imbricatus also included GA and myricetin compounds. It was highly effective on GST activity at all doses. Marcotullio et al. ${ }^{33}$ reported that the methanol extract of $S$. imbricatus contained high amounts of polyphenol contents, which can explain the radical scavenging activity.

In the present study, it was found that the ethanol extract of 1. hispidus contained high amounts of phenolic and flavonoid contents, which suggests that the high potential effects of free radical scavenging activity may be raised due to the large amounts of polyphenolic profiles. The low dosage of $I$. hispidus extracts showed an elevated effect on GST activity. The ethanol extract of $I$. hispidus also demonstrated a slight antimicrobial effect on the bacterial strains. In another study, the inhibitory effect of phenolic compounds and alkaloids of I. hispidus was investigated on the lipase of Candida rugosa. ${ }^{34}$ It was observed that the phenolic and alkaloid extracts were efficient inhibitors of the lipase of C. rugosa. Therefore, it was suggested that these compounds could be used in the treatment of candidiasis. The obtained results also indicated that the phenolic extracts showed stronger radical scavenging activity than the alkaloids extracts. $^{34}$

In our study, $R$. chloroides included very low amounts of polyphenolic contents and showed antioxidant and antimicrobial activities. On the other hand, HPLC analysis showed that the ethanol extract of $R$. chloroides contained remarkable amounts of ferulic acid, myricetin, and GA compounds. However, the effect of this extract on GST enzyme activity was negligible.

\section{CONCLUSIONS}

In the present research, the biological activity and detoxification potential of the polyphenol contents isolated from $G$. adspersum, I. hispidus, $R$. chloroides, and $S$. imbricatus species were investigated for their free radical scavenging and GST enzyme activities. It was found that the ethanol extract of $I$. hispidus had large amounts of phenolic and flavonoid contents. It was also observed that this ethanol extract had a high level of free radical scavenging potential. This activity may be attributed to the high concentration of polyphenol compounds in the ethanol extract of $I$. hispidus. Moreover, the ethanol extract of $I$. hispidus had a significant potential to increase GST enzyme activity, which plays a critical role in detoxification pathways. Therefore, I. hispidus was suggested to be a new potential source of natural medicine.

\section{ACKNOWLEDGEMENTS}

This work was financially supported by the Coordination of Scientific Research Projects of Ankara University (Research Project No: 16H0430011 and 15H0430001) in Turkey.

Conflict of Interest: No conflict of interest was declared by the authors. 


\section{REFERENCES}

1. De Silva DD, Rapior S, Sudarman E, Stadler M, Xu J, Alias SA, Hyde KD. Bioactive metabolites from macrofungi: ethnopharmacology, biological activities and chemistry. Fung Diver. 2013;62:1-40.

2. Loria-Kohen V, Lourenco-Nogueira T, Espinosa-Salinas I, Marin FR, Soler-Rivas C, Ramirez de Molina A. Nutritional and functional properties of edible mushrooms: A food with promising health claims. J Pharm Nutr Sci. 2014;4:187-198.

3. Hansen MB, Jensen ML, Carstensen B. Causes of death among diabetic patients in Denmark. Diabetologia. 2012;55:294-302.

4. Kozarski M, Klaus A, Jakovljevic D, Todorovic N, Vunduk J, Petrović P, Niksic M, Vrvic MM, Van Griensven L. Antioxidants of Edible Mushrooms. Molecules. 2015;20:19489-19525.

5. Liu GT. Recent advances in research of pharmacology and clinical applications of Ganoderma (P. Korst.) species (Aphyllophoromycetideae) in china. IJ of Med Mushrooms. 1999:63-67.

6. Smina TP, Mathew J, Janardhanana KK, Devasagayam TP. Antioxidant activity and toxicity profile of total triterpenes isolated from Ganoderma lucidum (Fr.) P. Karst occurring in South India. Environ Toxicol Pharmacol. 2011;32:438-446.

7. Vazirian M, Dianat S, Manayi A, Ziari R, Mousazadeh A, Habibi E, Saeidnia S, Amanzadeh Y. Anti-inflammatory effect, total polysaccharide, total phenolics content and antioxidant activity of the aqueous extract of three basidiomycetes. Res J of Pharma. 2014;1:15-21.

8. Rajoriya A, Tripathy SS, Gupta N. In vitro antioxidant activity of selected Ganoderma species found in Odisha, India. Trop Plant Res. 2015;2:72-77.

9. Ivone HA, Jorge MT, Guadalupe GRM, Berenice YJ. Total Polyphenols and Antioxidant Activity of Ganoderma curtisii extracts. J of Med Plants Studies. 2016;4:136-141.

10. Wong KL, Chao HH, Chan P, Chang LP, Liu CF. Antioxidant Activity of Ganoderma lucidum in Acute Ethanol-induced Heart Toxicity. Phytother Res. 2004;18:1024-1026.

11. Çayan-Tel G, Öztürk M, Duru ME, Rehman MU, Adhikari A, Türkoğlu A, Choudhary MI. Phytochemical investigation, antioxidant and anticholinesterase activities of Ganoderma adspersum. Indust Crops and Prod. 2015;76:749-754.

12. Kim SK. Method for making seasoned pork ribs by using Sarcodon aspratus and Acanthopanax senticosus broth for aging pork ribs. Patent KR. 2006:128485.

13. Ueno T, Yaoita Y, Kakuda R, Machida K, Kikuchi M. Studies on the constituents of mushrooms. VII. On the sterol constituents from the fruit bodies of Sarcodon aspratus. J of Tohoku Pharma Uni. 1999;46:71-76.

14. Yue H, Zejun D, Jikai L. Chemical constituents from the basidiocarp of Sarcodon aspratum. Acta Botanica Yunnanica. 2002;24:125-128.

15. Takei T, Yoshida M, Ohnishi-Kameyama M, Kobori M. Ergosterol peroxide, an apoptosis-inducing component isolated from Sarcodon aspratus (Berk.) S. Ito. Biosci Biotechnol Biochem. 2005;69:212-215.

16. Kobori M, Yoshida M, Ohnishi-Kameyama M, Takei T, Shinmoto $H$. 55alpha,8alpha-Epidioxy-22E-ergosta-6,9(11),22-trien-3beta-ol from an edible mushroom suppresses growth of HL60 leukemia and HT29 colon adenocarcinoma cells. Biol Phar Bull. 2006;29:755-759.
17. Kobori M, Yoshida M, Ohnishi-Kameyama M, Shinmoto H. Ergosterol peroxide from an edible mushroom suppresses inflammatory responses in RAW264.7 macrophages and growth of HT29 colon adenocarcinoma cells. Br J Pharmacol. 2007;150:209-219.

18. Awadh Ali NA, Mothanaa RA, Lesnau A, Pilgrim H, Lindequist U. Antiviral activity of Inonotus hispidus. Fitoterapia. 2003;76:483-485.

19. Sheehan D, Meade G, Foley VM, Dowd CA. Structure, function and evolution of glutathione transferases: implications for classification of non-mammalian members of an ancient enzyme superfamily. Biochem J. 2001;360:1-16.

20. Nebert DW, Vasiliou V. Analysis of the glutathione-S-transferase (GST) gene family. Human Genomics. 2004;1:460-464.

21. Onar O, Akata I, Celep GS, Yildirim O. Antioxidant Activity of Extracts from the Red-Belt Conk Medicinal Mushroom, Fomitopsis pinicola (Agaricomycetes), and Its Modulatory Effects on Antioxidant Enzymes. Int J Med Mushrooms. 2016;18:501-508.

22. Slinkard K, Singleton VL. Total phenol analyses: Automation and comparison with manual methods. Am J Enol Vitic. 1977;28:49-55.

23. Chang CC, Yang MH, Wen HM, Chern JC. Estimation of total flavonoid content in propolis by two complementary colorimetric methods. J Food Drug Anal. 2002;10:178-182.

24. Sharma OP, Bhat TK. DPPH antioxidant assay revisited. Food Chem. 2009;113:1202-1205.

25. Moghaddam NS, Isgor BS, Isgor YG, Geven F, Yildirim O. The Evaluation of Inhibitory Effects of Selected Plant Extracts on Antioxidant Enzymes. Fresenius Enviro Bull. 2015;4:63-70.

26. Lowry OH, Rosebrough NJ, Farr AL, Randall RJ. Protein measurement with the Folin phenol reagent. J Biol Chem. 1951;193:265-275.

27. Habig WH, Pabst MJ, Jakoby WB. Glutathione-S-transferases the first enzymatic step in mercapturic acid formaion. J Biol Chem. 1974;249:71307139.

28. Silici S, Koc AN. Comparative study of in vitro methods to analyse the antifungal activity of propolis against yeasts isolated from patients with superficial mycoses. Lett Appl Microbiol. 2006;43:318-324.

29. Kandaswami C, Lee LT, Lee PP, Hwang JJ, Ke FC, Huang YT, Lee MT. The antitumor activities of flavonoids. In Vivo. 2005;19:895-909.

30. Chirumbolo S. The role of quercetin, flavonols and flavones in modulating inflammatory cell function. Inflamm Aller Drug Targets. 2010;9:263-285.

31. Yao Y, Lin G, Xie Y, Ma P, Li G, Meng Q, Wu T. Preformulation studies of myricetin: a natural antioxidant flavonoid. Pharmazie. 2014;691:19-26.

32. Kuruni N, Mallıkarjun N, Naika R, Venugopal TM. Antioxdative Activities of Wild Macro Fungi Ganoderma applanatum (PERS.) PAT. Asian J Pharm Clin Res. 2014;7:166-171.

33. Marcotullio MC, Oball-Mond Mwankie GN, Cossignani L, Tirillini B, Pagiotti R. Phytochemical analysis and antiradical properties of Sarcodon imbricatus (L.:Fr) Karsten. Natu Prod Commun. 2008;3:1907-1910.

34. Benarous K, Bombarda I, Iriepa I, Moraleda I, Gaetan H, Linani A, Tahri D, Sebaa M, Yousfi M. Harmaline and hispidin from Peganum harmala and Inonotus hispidus with binding affinity to Candida rugosa lipase: In silico and in vitro studies. Bio Chem. 2015;62:1-7. 